al-Ihkam: Jurnal Hukum dan Pranata Sosial, 15 (1), 2020: 67-92

ISSN: 1907-591X, E-ISSN: 2442-3084

DOI: http://dx.doi.org/10.19105/al-lhkam.v15i1.2883

\title{
The Implementation of PERMA Number 3 of 2017 Concerning the Guidelines for Dealing with Women's Cases on Laws as an Effort of Women Empowerment in The Judiciary in Madura
}

\author{
Siti Musawwamah \\ Syariah Faculty, IAIN Madura, Jl. Raya Panglegur, Km. 04 Tlanakan, \\ Pamekasan 69371 \\ Email:mamahtaufiq@yahoo.com
}

Article history: Received: 27 April 2019, Accepted: 11 March 2020, Published: 27 June 2020

\begin{abstract}
:
Women empowerment in the judiciary institution had actually been sought since the moment of rule enforcement on reasons for divorce and implementation of (valid) divorce before a court hearing. This policy is an affirmation of legal renewal in the UUP (marriage law) and KHI (Compilation of Islamic Law) as well as an entry point for the law protection on women through the guarantee of legal certainty and opportunity to fight for their rights in divorce decisions, including right of gaining nafkah mädiyah (past/indebted), nafkah 'iddah, nafkah mut'ah, shared assets, hadānah (child custody) and childcare costs. The problem relates to the execution of the judiciary decision as it deals with some problems. One of which is the fact that there found no rule regarding with mechanism/method as well as the time limit for the implementation, while the divorce pledge would be expired within 6 months after the decree of pledge permission. Accordingly, the Supreme Court's policy to issue PERMA number 3 of 2017 concerning the guidelines for dealing with women's cases in law shows its significance. Using a qualitative research design, this
\end{abstract}

Author correspondence email: mamahtaufiq@yahoo.com Available online at: http:/ / ejournal.iainmadura.ac.id/index.php/alihkam/ Copyright (c) 2020 by al-ihkam. All Right Reserved 
Siti Musawwamah

paper aimed at describing the implementation of PERMA number 3 of 2017 in religious courts in Madura, identifying constraints in its implementation, and explaining in detail the solutions to overcome the constraints. The results of this study are expected to be beneficial as an attempt to empower women by removing all barriers they cope with. Furthermore, it also enables them to gain access to justice without any discrimination in the justice system particularly in the religious court system at all levels, namely the first level, appeal, and cassation.

Keywords:

PERMA Number 3 of 2017; Women Empowerment; The Judiciary

\begin{abstract}
Abstrak:
Pemberdayaan perempuan di lembaga peradilan sesungguhnya sudah diupayakan sejak penormaan tentang alasan-alasan perceraian dan pelaksanaan (keabsahan) perceraian di depan sidang pengadilan. Kebijakan ini merupakan penegasan kebaruan hukum dalam UUP (Undang-Undang Perkawinan) dan KHI (Kompilasi Hukum Islam) sekaligus menjadi pintu masuk upaya perlindungan hukum terhadap perempuan, yaitu adanya jaminan kepastian hukum dan kesempatan untuk memperjuangkan hak-hak mereka dalam putusan perceraian, meliputi hak untuk mendapatkan nafkah mädiyah (nafkah lampau/terhutang), nafkah'iddah, mut'ah, bagian harta bersama, hadīnah (hak asuh anak) dan biaya pengasuhan anak. Problemnya adalah terkait eksekusi putusan, dalam praktiknya banyak mengalami kendala karena ketiadaan aturan tentang mekanisme/cara dan batas waktu pelaksanaannya, sementara waktu ikrar talak dibatasi maksimal 6 (enam) bulan setelah ditetapkan hari sidang tentang izin ikrar talak. Pada posisi inilah kebijakan Mahkamah Agung menetapkan PERMA Nomor 3 Tahun 2017 Tentang Pedoman Mengadili Perkara Perempuan Berhadapan dengan Hukum
\end{abstract}


menampakkan signifikansinya. Dengan menggunakan desain penelitian kualitatif tulisan ini bertujuan mendeskripsikan penerapan PERMA Nomor 3 Tahun 2017 di lembaga Peradilan Agama se wilayah Madura, mengidentifikasi kendala penerapannya, dan menjelaskan secara rinci atas solusi mengatasi kendala penerapannya. Hasilnya diharapkan dapat memberdayakan perempuan dengan menghapus segala hambatan bagi perempuan memperoleh akses keadilan dan membebaskan dari segala bentuk diskriminasi dalam sistem peradilan termasuk sistem peradilan agama di semua tingkatan, yaitu tingkat pertama, banding dan kasasi.

\section{Kata Kunci:}

PERMA No. 3 Tahun 2017; Pemberdayaan Perempuan; Lembaga Peradilan

\section{Introduction}

On July 17, 2017, the Supreme Court of the Republic of Indonesia known as MARI had stipulated "pro-women" regulation in the form of Supreme Court Regulation Number 3 of 2017 concerning guidelines for adjudicating women's cases on the law (PERMA-Peraturan Menteri Agama, The Ministry of Religious Affair's Rule-Number 3 of 2017). ${ }^{1}$ The legal mandate of this regulation is MARI's commitment to empowering women in the judiciary through removing all of their obstacles, enabling them to gain access to justice and freeing them from any type of discrimination in the justice system including those in the first level of religious justice system, appeal and cassation.

As commonly known, in many legal cases, women are still inferior to men. For example, in divorce cases, women generally do not get enough legal protection due to the lack of certainty on post-

1 "PERMA Nomor 3 Tahun 2017 Tentang Pedoman Mengadili Perkara Perempuan Berhadapan Dengan Hukum," 2018, Accessed on June 10, 2018. 
divorce rights they and their children deserve. ${ }^{2}$ The condition remains the same unless they file a reconvention lawsuit (counterretribution) in divorce cases or accumulation (merging of claims) in divorce suitcases. If the judges do not use their ex-officio rights (rights inherent in the office of judge), women will even be the losers after the divorce verdict because they have to take responsibility for their survival and their children while the men (husbands) are free from any obligations. ${ }^{3}$

Another problem relates to the execution of divorce decision as there found no rules about method and time limit for its implementation ${ }^{4}$ while at the same time, the divorce pledge is limited to six months at maximum after the trial day on the approval of divorce pledge as stipulated in Article 131 paragraph (4) of KHI as follows:

"If the husband does not declare the divorce pledge within six months since the decision of the Religious Court regarding the permission of the divorce pledge for him to have permanent legal force, then the husband's right to pledge the divorce becomes invalid and the marriage ties remain intact" 5

The deadline for divorce pledge gives a big dilemma for women who file reconvention claims against their husbands. Although the Court might grant all or some parts of a lawsuit for their and their children's rights, the husbands remain the determining factor. Husbands who do not get well committed to the deadline of the divorce pledge will abuse it to punish the wives by not carrying out the divorce pledge until the six months expires. As a result, the verdict was declared null and void by law while the

2 Ahmad Tholabi Kharlie, "Modernisasi, Tradisi, Dan Identitas: Praktik Hukum Keluarga Islam Indonesia," Studia Islamika 18, no. 1 (2011): 167-99, https://doi.org/10.15408/sdi.v18i1.444.

3 Siti Musawwamah et al, "Penelitian Sosio-Legal Penyelesaian Kasus KDRT Di Pengadilan Agama Wilayah Madura," 2015, 147.

4 Syaiful Annas, "Masa Pembayaran Beban Nafkah Iddah Dan Mut'ah Dalam Perkara Cerai Talak (Sebuah Implementasi Hukum Acara Di Pengadilan Agama)," Al-Ahwal 10, no. 1 Juni (2017): 2.

5 "Kompilasi Hukum Islam" (1991), See article 131 paragraph 4. 
marriage is considered to be still officially intact as if a divorce process had never taken place.

That situation puts the wives in a big difficulty and dilemma between de facto that they do not live in a marriage institution anymore as husband and wife and on the other hand, de jure that they do not divorce because their marriage has not been declared broken. The choice often becomes complicated between surviving an unmarried marriage and getting divorced by taking initiative to file for divorce suit with the risk of not obtaining their and their children's rights because the husbands will certainly not attend to the court and finally the verdict is made in verstek.

The problem remains serious for women hitherto. A case shows how hard it was for a wife who was divorced by her husband while he did not pledge for divorce declaration until the deadline of six months. They lived apart as they have divorced; the husband lived alone and the children lived with the wife.

Dealing with this, the wife persisted not filling for divorce suit to the court because she did not want to lose her and children's rights along with her husband's arrogance. The uncertain-or hanging up-position of marital status lasted for two years and finally ended when the husband took the initiative to file for divorce again because he needed legality of the single status as a requirement of carrying out a marriage with another woman. ${ }^{6}$

The same problem has also been experienced by a wife with three daughters who got divorced by her husband on the charge of always being jealous and accusing him of having an affair with another woman. In the court, the wife could reveal the fact that her husband did not only have an affair with another woman but also got married through sirri (unofficial) ones and got a daughter. Realizing that she had to support the children by herself, the wife demanded her and the children's rights up to the cassation level.

\footnotetext{
${ }^{6}$ The first divorce pledge was through a decision no: 092/Pdt.G/2015/PA.Pmk while the appeal verdict was no: 0032/Pdt.G/2016/PTA.Sby while the second divorce was on the decision no: 0173/Pdt.G/2018/PA.Pmk.
} 
Unfortunately, the husband did not comply with the cassation decision by not declaring the divorce pledge until the deadline of six months. As a result, the verdict was null and void by law while the marriage remained intact. After two years, the husband filed for divorce again while the wife, due to her persistence in fighting for her and her children's rights, found her demand granted by the judges at the cassation panel in the form of nafkah madliyah for five years, nafkah'iddah, mut'ah, and nafkah for three children. ${ }^{7}$

Those two cases show how big a dilemma for women is as the common condition often puts the status of divorce at risk. If the husband does not declare the divorce pledge until the deadline of six months, the divorce process will be considered never happen before even though in reality, both have long been separated. In other words, maintaining the fulfillment of post-divorce rights is a difficult choice for women because it implies the divorce status and survival of herself and her children. In this position, the implementation of PERMA number 3 of 2017 shows its significance to empower women in the judiciary, namely eradicating the injustice for them either because what their husbands do or the how legal system is gender biased as it is fully not in favor of women.

As a follow-up to PERMA number 3 of 2017, the Supreme Court has issued a Supreme Court circular number 1 of 2017 concerning the implementation of the results of the Supreme Court plenary meeting in 2017 (SEMA Number 1 of 2017). Its letter C (1) mentions that in the framework of PERMA number 3 of 2017 and to provide legal protection for women's rights after divorce, the method of payment can be explicitly written in the decision with the sentence "paid before the pledge of divorce" unless the wife wants otherwise.

The studies on the Supreme Court regulation on guidelines for adjudicating women in law cases (PERMA number 3 of 2017)

\footnotetext{
${ }^{7}$ The first divorce pledge was through decision of Pamekasan Religious Court number : 0233/Pdt.G/2011/PA.Pmk and cassation decision number: 559K/AG/2012, while the second divorce was through Pamekasan Religious Court: Number: 0209/2014/PA.Pmk.
} 
have not been much conducted since it is a relatively new issue in legal research. Precisely as stated before, this "pro-woman" regulation was only adopted on July 17, 2017 and aims to remove women's obstacles to gain access to justice and free them from any forms of discrimination in the Indonesian justice system in including those on the religious court at all levels, first level, appeal and cassation. Even so, several related previous studies are available as follow:

First, a library research on maslahah (advantageous) analysis of PERMA number 3 of 2017 concerning the guidelines for adjudicating women's law cases. It aims to find out the background of the establishment of the PERMA and analyze it based on maslahah theory. Results of the study concluded that the establishment of the PERMA closely relates to the practical fact that the Indonesian justice system was still full of discrimination and gender stereotypes. Therefore, the PERMA can be interpreted as a form of partiality to women as it aims to eliminate all forms of discrimination and legal dysfunction of women's rights enforcement.

In the maslahah perspective, the "pro-women" regulation is categorized as a maslahah hajiyah because women dealing with law cases or become litigants need it to facilitate their legal processes and assure sustainability of their lives. Without the good implementation of the PERMA, women will find many problem as it will materially and non-materially give them negative impact. ${ }^{8}$

Second, a research on the effect of PERMA number 3 of 2017 concerning the divorce cases in Kediri Religious Court before and after the stipulation of the PERMA. The study aims to identify the differences in divorce decisions before and after the stipulation of the PERMA as well as to find out any existing obstacles to the PERMA's implementation in deciding divorce cases at Kediri

${ }^{8}$ Silmi Mursidah, "Analisis Maslahah Terhadap PERMA No. 3 Tahun 2017 Tentang Pedoman Mengadili Perkara Perempuan Berhadapan Dengan Hukum" (UIN Sunan Ampel Surabaya, 2017),Accessed on August 15, 2018. 
Religious Court. Using the juridical-normative (doctrinal) research methods, the study found these following points:

First is the fact about differences decision of the divorce petition after the stipulation of PERMA. This is clear from the existence of an order to pay nafkah iddah, mut'ah and madliyah before the declaration of divorce pledge. Meanwhile, in the divorce suit decision, there found no differences after enactment of the PERMA.

The Second is about the constraints to implementing the PERMA which relates to a paradigm of judges in interpreting the concept of wives' nusyuz (betrayal) which results in nullification of the wives' right after divorce. Another constrain is the factual conditions of certain disputing parties, especially the husband with a low economic level which makes the judge find it difficult to determine the payment of the settlement obligations after the divorce. ${ }^{9}$

Third, a study on the role of the Religious Court in protecting the rights of women and children through friendly and implementable decisions written by Amran Suadi, the judicial chairperson of the Indonesian Supreme Court. This study concluded that in response to the lack of realization of the divorce verdict including the fulfillment of wives and children's right after the divorce and as an effort to protect women and children, the Indonesian Supreme Court has made a new policy at RAKERNAS 2017 held in Bandung to issue SEMA Number 1 of 2017 concerning the imposition of the results of the 2017 Supreme Court's Plenary Meeting as a guideline to implement the duties for the judiciary institution.

One of its important results is the establishment of the rules that in the framework of implementing PERMA number 3 of 2017 and protecting the rights of women after divorce, the payment of obligation due to divorce, especially iddah, mut'ah, and nafkah madliyah can be explicitly included in the verdict with the sentence "paid before the pronouncement of divorce pledge". However, a

9 Nauval Rikza, "Pengaruh PERMA No. 3 Tahun 2017 Terhadap Perkara Perceraian Di Pengadilan Kabupaten Kediri" (Universitas Muhammadiyah Surakarta, n.d.), Accessed on August 15, 2018. 
divorce pledge can still be implemented if the wife does not mind when the husband does not pay the obligation at the time. This provision becomes legal protection for the Religious Court to make decisions that protect women because in some cases, implementation of the divorce pledge tends to ignore women's position and situation. ${ }^{10}$

The mentioned previous studies show that this research corroborates the research findings of the position of the PERMA that the MARI's policy can serve as legal protection for Religious Courts to make decisions that protect women (and children) by fulfilling the benefit (maslahah hajjiyah) for women dealing with law cases. It mainly eradicates women's obstacles to gain access to justice and equality in the justice system. For this reason, this research focuses to identify the implementation strategies, obstacles and disclosing solutions to the application of the PERMA number 3 of 2017 on Religious Courts in the Madura.

\section{Method}

Using a qualitative research design,11 this study aims to describe the implementation strategy of PERMA number 3 of 2017 in Religious Court institutions in Madura to identify obstacles to its implementation and to explain the solutions in detail. The primary data are interview results from judges who have received, examined, and decided women's cases dealing with the law, while secondary data are divorce documents, divorce claims, wife's living claims, children's livelihood claims, mut'ah and hadlonah. Research data were collected using interactive methods through in-depth interviews and participatory observation, while the non-interactive method was directed at analyzing the contents of documents. ${ }^{12}$

${ }^{10}$ Amran Suadi, "Peranan Peradilan Agama Dalam Melindungi Hak Perempuan Dan Anak Melalui Putusan Yang Memihak Dan Dapat Dilaksanakan," Majalah Hukum Varia Peradilan Tahun XXXIII. No. $390 \mathrm{Mei}$ 2018 (Jakarta, 2018), 22.

11 Zainuddin Ali, Metode Penelitian Hukum, 4th ed. (Jakarta: Sinar Grafika, 2013), 105.

12 Johnny Ibrahim, Teori Dan Metodologi Penelitian Hukum Normatif, 6th ed. (Malang: Bayumedia Publishing, 2012), 272. 
The use of interviews, observations, and documentation as data collection techniques intend to obtain holistic and integrative data about the focus of research. Data analysis is the process of systematic information tracking and regulation of field notes and is carried out through data organizing activities during and after the collection of research data in the field. ${ }^{13}$

The checking process of validity and interpretation of the data aims to obtain valid research findings. For this purpose, a credibility, dependability, and data confirmability test were performed. Checking the validity of the data aims to prove that the recorded data is by the existing conditions and actual occurrence. Particularly in qualitative research, the validity of the data aims to meet the criteria of the emic truth value of the research information and findings. ${ }^{14}$

\section{Discussion and Result}

The investigation on divorce cases in a court hearing in the Religious Courts at Madura is not conducted rigorously by questioning the exact cause of disputes between husband and wife that lead to filing for divorce. This is mainly because the Court applies the concept of a broken home. No matter what the cause of the split is, the panel of judges considers mostly the consequences and a fact that the spouse's household has failed in achieving the goal of marriage to establish a happy and eternal household or sakinah, mawaddah and rahmah.

Therefore, the panel of judges thinks it is not important to know on whoch one makes the mistakes and what causes the disputes or quarrels. For the panel of judges, the most important thing is to know the real situation that the household of the disputing parties (the applicant and the respondent or the plaintiff

${ }^{13}$ Zainuddin Ali, Metode Penelitian Hukum.

${ }^{14}$ Lexy J Moleong, Metodologi Penelitian Kualitatif (Bandung: Remaja Rosdakarya, 1990), 188. 
and the defendant) has been broken or separated and there found no possibilities for recovery. ${ }^{15}$

Additionally, the references for examining and deciding divorce cases are legal references commonly referred to in the Religious Courts, namely UUP Article 39 (2) which mentions: "To conduct a divorce, there must be sufficient reasons and condition in which husband and wife can't live in harmony anymore", PP Article 19 (f) jo KHI Article 116 (f) which red; "Between husband and wife, there found continual disputes and quarrels and therefore it can't be expected for them both to live the household life in harmony "and Jurisprudence of MARI Number: 38K / AG / 1990 dated October 5, 1990 which says: "If the Judge is certain that the broken heart of both becomes the cause of the household breakup, then the purpose of article 19 (f) PP number 9 of 1975 has been fulfilled and consequently, the only way to take fairly is divorce.

Even so, in some divorce cases, the panel of judges also referred to other laws such as Law number 35 of 2014 concerning amendments to Law number 23 of 2003 on child protection. This implies that within certain limits, the panel of judges also referred to other laws besides the commonly referred one in Religious Courts. In other words, panel of judges in Madura Religious Courts has begun to be open on the development of new laws related to their field of work, such as enacting PERMA number 3 of 2017 under legal considerations. Following are description on research focus(es) namely implementation of PERMA number 3 of 2017 in Religious Courts at Madura, its implementation constraints and solutions.

1. The Implementation Strategy of PERMA number 3 of 2017 in the Religious Court at Madura

15 Narendra Subramanian, "Islamic Norms, Common Law, and Legal Reasoning: Muslim Personal Law and the Economic Consequences of Divorce in India," Islamic Law and Society 24, no. 3 (2017): 254-86, https://doi.org/10.1163/15685195-00243p03. 
The research finding shows that several judges as informants in this study had implemented the strategy of PERMA number 3 of 2017. This includes as follow:

First, at the initial stage of trial, after the mediation was declared unsuccessful, the panel of judges explained the rights of wife and child(ren) after divorce. However, this only happens if the disputing parties come to the hearing process because if they don't and therefore are represented to the lawyer, the explanation is skipped. After all, it was commonly understood. The explanation is very useful for both because the husband will pay the obligations and he will receive it. Moreover, in court practice, most the wives generally do not understand their and their children's rights after divorce. Likewise, this explanation will be useful to make the husband prepared in fulfilling the obligation so that the divorce process does not drag on and take too much time. ${ }^{16}$

Second, the judge actively engages in the trial process even though one of the basic principles of civil procedure requires them to be passive. This particularly happens in dealing with a silent wife who does not talk much. In this condition, the judge typically helps to explain both her position and rights to give her support and courage in claiming her and her children's right at the answer stage of the trial. This change of judge's attitude finds its relevance or legitimacy at PERMA number 3 of 2017 saying that he/she serves as an "enforcer of justice" instead of a "case breaker" in the court hearing. ${ }^{17}$ In specific, article 8 paragraph (2) PERMA number 3 of 2017 mentions that the judge is encouraged to be active in the trial in the sense that he/she needs to explain and make the wife understand her rights after the divorce which can be prosecuted in the trial in accordance to applicable procedural law.

The provision of PERMA number 3 of 2017 seems to deviate from another provision of the civil procedural law which puts the judge at a passive position according to "ultra petita" doctrine.

16 Sulhan Fadlil, "The Chief of Sumenep Religious Court," (n.d.), Direct interview on May 16, 2019 at 10.00.

17 Khoiruddin Nasution, "Peran Kursus Nikah Membangun Keluarga Sejahtera," AHKAM:Jurnal Ilmu Syariah 15, no. 2 (March 2016), https://doi.org/10.15408/ajis.v15i2.2862. 34 
However, Article $119 \mathrm{HIR} /$ Article $143 \mathrm{RBg}$ mentions that in certain conditions, the judge is supposed to be active in settling civil disputes, for example when the chair of judges panel advises the plaintiff or the attorney on requirements to make the suit accepted. Additionally, Article $130 \mathrm{HIR} /$ Article 154 the RBg also confirms that the judges must first be active in reconciling engaging parties while Article $132 \mathrm{HIR} /$ Article $156 \mathrm{RBg}$ requires them to also play an active role to inform both parties as well as provide an explanation on a right to make a counter-claim justified by the law and a right to submit evidence in court.

Relating to this, Mukti Arto, the judge of the Indonesian Supreme Court, said that it is possible to distort the doctrine of "ultra petita" to provide legal protection and justice for women and children in divorce cases. He took an example from a divorce case because of a husband's mistakes which destroy the household's harmony. In this case, to provide legal protection and justice for the wife, the husband must give proper nafkah mut'ah and nafkah 'iddah as the punishment for what he did. If the wife does not ask for it, the panel of judges under the ex officio can determine it as the husband's obligation and the wife's right based on the provisions of Article 41 letter c UUP.

Additionally, if hadhanah of an immature child belongs to his/her mother, the father might provide nafkah through the mother as his punishment as well. In other words, for the sake of the protection and economic survival of the child, the panel of judges under the ex officio may require the father to bear the cost of the child's livelihood based on the provisions of Article 156 (f) KHI.

Third, the judge generally uses his/her legal mandate, namely the ex officio right, to determine the wives and children's rights in decisions assured by regulation and law. Unfortunately, practical use of the ex officio rights is still restricted for specific cases in which the wives do not want a divorce because they still love the husbands and for the sake of their children. ${ }^{18}$ The legal mandate is based on Article 41 of the UUP mentioning that divorce has some

18 Aminah, "A Judge in Sampang Religious Court," (n.d.), Direct interview on June 17, 2019 at 110.00 . 
following legal consequences to carry out by both ex-husband and ex-wife because of the termination of marriage due to their separation:

a. Both are still obliged to take care of and educate their children for the children's good. Any dispute on the childcare right will be subject to the court to decide.

b. Fathers are still responsible for all maintenance and education costs of their children. If they are unable to do that, the court can decide to engage the ex-wife (mothers) in paying the costs;

c. The court may require the ex-husband to afford the living cost of the ex-wife and/or determine his obligation for this purpose.

A more detailed description of Article 41 of the UUP is found in Article $149 \mathrm{KHI}$. It regulates that in any marriages which break up due to divorce, the ex-husbands are obliged to:

a. Give proper mut'ah to his ex-wife either money or property unless the ex-wife is still virgin (having no sexual intercourse during the marriage or qabla aldukhul);

b. Give living (nafkah), shelter (maskan), and clothing (kiswah) to the ex-wife during the 'iddah period unless the ex-wife has been under $b \bar{a}$ 'in divorce or nusyūz and not pregnant;

c. Pay off the owed dowry either entirely or partially or if the wife is still a virgin, (having no sexual intercourse during the marriage or qabla al-dukhul), it counts half of the dowry's common values.

d. Pay the cost of childcare (hadānah) before the children reach 21 years old. ${ }^{19}$

Formulation of legal rights for wives and children after divorce is designed to guarantee for protecting their rights because in many cases, they frequently become victims. The affirmation of divorce validity before the court hearing, for instance, is a clear sign of legal protection for the wife because this avoids her husband

${ }^{19}$ Kompilasi Hukum Islam. 
being too dominant or arbitrary in proposing divorce. Besides, wives are also possible to submit and defend their rights, including the rights of their children because, in most of the divorce cases, children live with and are cared for by their mothers.

Substantially, the provision of Article 41 of the UUP and article 149 of KHI stipulate direct obligations that a husband needs to fulfill on his ex-wife and children after divorce. Therefore, the judge can apply the provision even though the wife does not file any lawsuit. In legal terms, the procedural power of the judge is called ex officio right, namely an attached and exclusive right for judges to determine the husband's obligations even without any claim from the wife as another party.

Unfortunately in a practical way, the ex officio rights are often restricted and consequently, the court's decision only functions to decide a case without really solving the problem. In a divorce case when a husband files a suit to divorce his wife while the wife does not submit for her and children's rights in the reconciliation lawsuit, for example, the divorce decision only includes aspects of legal certainty regarding termination of the marriage. It excludes the aspects of divorce justice and expediency. ${ }^{20}$

For some wives who are not accustomed to work and earn money, the situation puts the sustainability of their and their children's lives at risk. Likewise, if they serve as the plaintiffs in a divorce case without submitting cumulative rights, the condition will remain the same; the divorce verdict only fulfills the main claim on the marriage termination without any certainty of protection of post-divorce rights for herself and her children. As a consequence, it is the wife who will assume all obligations on the children's rights, while the husband is free from any obligations. In this context, the court can be categorized as having impunity

20 Siti Musawwamah, "Perlindungan Hak-Hak Perempuan Dan Anak Pada Putusan Perceraian Di Pengadilan Agama Pamekasan Tahun 2012-2014" (UIN Sunan Kalijaga Yogyakarta, 2019), 12. 
(negligence) to husbands who neglect their obligations on their wives and their children. ${ }^{21}$

For all of these reasons, now is the right momentum for judges to apply PERMA number 3 of 2017 in legal considerations namely providing legal breakthroughs through several aspects. One of the most urgent things is determining the payment period for women and children's rights after divorce to facilitate the benefits as clear in certainty, usefulness, and justice for women.

Fourth, the delay of the divorce pledge if it expires the maximum time of 6 months while the husband has not paid the obligations to his wife and children. This is based on the provision of Article 131 paragraph (4) KHI. However, this strategy of delay does not aim to protect women because as explained earlier in certain cases, the norm is even misused by irresponsible. In another word, the norm can be a "boomerang" for some wives and therefore must be implemented carefully and meticulously. ${ }^{22}$

Those are some strategies for enacting PERMA number 3 of 2017 in 4 (four) Religious Courts in Madura according to the judges who engaged as informants in this study. Practically, however, those strategies still find difficulities in both technical and nontechnical constraints.

\section{The Constraints on the Implementation of PERMA number 3 of 2017 in Religious Court at Madura.}

From the perspective of law enforcement, this is a study on the operation of the law. Therefore, identifying the constraints of its implementation becomes very urgent, especially to find out some factors that influence its effectiveness. This research finds that the constraints on the implementation of PERMA number 3 of 2017 include as follow:

21 Siti Musawwamah, "Perlindungan Hak-Hak Perempuan Dan Anak Pada Putusan Perceraian Di Pengadilan Agama Pamekasan Tahun 2012-2014."

22 Fadlilah, "A Judge in Bangkalan Religious Court," (2019) Direct interview on June 24, 2019 at 09.00. 
First, in a divorce suitcase, the wife generally only demands a principal claim, namely the breaking of marriage ties or divorce, while the husband typically does not attend the trial so the verdict is finally made in a verstek manner. In this position, the wife has lost her rights after divorce, except the right of the child (child living) which can be determined using ex officio right of judges.

However, this only applies when the husband works as a public servant. The purpose of determining children's right in the decision intends to evidence that the judge stands by the protection of children. Additionally, it will also be used as authentic evidence before the treasurer of salary payments. In other word, PERMA number 3 of 2017 has not been seriously implemented in divorce cases. $^{23}$

Second, in a divorce case, likewise, usually the wife does not attend the trial even though she has been invited properly and lawfully. Based on the principle of civil procedure law, if the respondent is not present at the trial, the case will be terminated in verstek and the respondent is automatically deemed to have accepted the court's decision.

Third, the husband's economic capability sometimes becomes another obstacle in implementing PERMA number 3 of 2017. Practically, although the panel of judges has estimated a husband's ability on the nominal amount of payment for his exwife and children, it cannot always be carried out right away and this leads to the postponement of the pledge hearing divorce. ${ }^{24}$

Fourth, some cases in which the right to claim is filed after the process of the defendant's response. If there found a change in the lawsuit (addition or subtraction) to the main claim, it is supposed to be submitted before the panel of judges read the answer of the defendant. Conversely, if it is submitted after the reading of the answer session, it must obtain the defendant's approval. This provision is based on the Guide Book on the Implementation of Duties and Administration of the Religious

${ }^{23}$ Fadlilah.

${ }^{24}$ Umniyah, "A Judge in Pamekasan Religious Court," (n.d.), Direct interview on 15 June, 2012 at 10.00. 
Court, book II, revised edition of the year 2013 which mentions that: "the changes in a lawsuit made after an answer from the defendant must be with the defendant's approval". The problem arises as not all women who litigate in the judiciary know the standard procedure. ${ }^{25}$

Fifth, derivative (technical) regulation of PERMA number 3 of 2017 uses the diction "can" as stated in SEMA Number 1 of 2017 letter C (1): "in implementing PERMA number 3 of 2017 and providing legal protection for women's rights after divorce, the method of payment can be included in the ruling with the sentence "paid before the pledge of divorce" unless the wife wants otherwise." This implies that the normative provision tends to be compromise instead of imperative. In another word, the court may either include or exclude the method of payment in the divorce ruling decision. This normative provision seems to "not seriously" guarantee the legal certainty regarding payment of post-divorce rights before the divorce pledge.

Sixth, a quite serious issue in the implementation of PERMA number 3 of 2017 is a judge perspective and knowledge factor. An interview to a judge reveals that not all judges follow the development or dynamics of the new law in the court, including the applicability of PERMA number 3 of 2017 which contains guidelines for adjudicating women law cases. Therefore, it makes sense if there still found few decisions which have adopted the mandate of the PERMA. This, according to the judge, is because nowadays, there only a few workshops held to update the judge's knowledge and insight. ${ }^{26}$

Identification of various constraints on the implementation of PERMA number 3 of 2017 confirms the validity of Lawrence M. Friedman's legal effectiveness theory which states that the effectiveness of law and law enforcement depends on three legal elements, namely, the substance of the law, the structure of law, and the culture of law (legal culture). The truth of this theory has

${ }^{25}$ Nurul Hakimah, "A Judge in Sampang Religious Court," (n.d.), Direct interview 15 June 2019 at 16.00.

${ }^{26}$ Aminah, "A Judge in Sampang Religious Court." 
also been agreed upon by Indonesian legal experts including Soerjono Soekanto, Achmad Ali, and Romli Atmasasmita.

Furthermore, more detailed description of three elements that greatly affect the effectiveness of law is described as follows: Substance, namely the entire rule of law, legal norms, and legal principles, both written and unwritten including court decisions; Structure, which is the entire legal institution and its officials, such as the court and its judges, police institutions, and the others; Legal culture, namely opinions, beliefs, habits, ways of thinking and behaving of both law practitioners and society about law and various relevant phenomena. ${ }^{27}$

3. The Solution to Overcome Constraints in the Implementation of PERMA number 3 of 2017 in the religious courts in the Madura.

Although the panel of judges has determined the rights of wife and children in the divorce decision as well as the method of payment in accordance with the mandate of SEMA number 1 of 2017 letter (c) by including the words "paid before the pledge of divorce", the practice is still very dependent on both husband and wife. If the husband can afford all the rights of his ex-wife and children on the day of trial, the pledge of divorce can be carried out right away and the divorce is declared valid according to the law. Conversely, if he cannot do that on the day of trial, the pledge hearing is postponed until a maximum time limit of 6 months unless the wife wishes otherwise. In this context, the wife has a right to change the decision of post-divorce rights by reducing the nominal amount or even freeing the payment at all.

Those choices may seem difficult but there must be a firm stand so that the wife will not be in an uncertain marital status because the husband does not pay for her rights until the time limit of the pledge. If that happens, the wife will be much disadvantaged because she will cope with dilemmatic position. In de facto aspect, she has lived separately from the husband but in de jure, the

${ }^{27}$ Lawrence M. Friedman, Sistem Hukum Perspektif Ilmu Sosial, ed. M. Khozin (Bandung: Nusamedia, 2013), 240. 
marriage has not been terminated because the husband does not declare the divorce pledge yet until the time is up.

Dealing with this, the common solution that the judge takes is to retain the Divorce Deed if the husband does not pay for it on the day of trial but is considered able to afford it. This can happen if the wife agrees on the divorce pledge reading despite the postponement of her right's payment.

Following is an example of a decision that has enacted the PERMA.

Decision Number: 0217 / Pdt.G / 2019 / PA.Spg.

In its legal considerations, because the plaintiff's petition was granted, the plaintiff was permitted to declare divorce pledges on the defendant before the hearing of Religious Court at Sampang after the decision was legally binding. Based on article 41 letter (c) of the UUP, ex officio enables the court to require the ex-husband in providing living expenses and or determine an obligation for the ex-wife.

In accordance with Article 149 letters (a and b) jo. Article 152, 158 letters (b) KHI, the ex-husband must: (a) give the appropriate $m u t^{\prime}$ ah to his ex-wife, either in the form of money or objects, except if the wife is in the condition of qabla dukhul, (b) provide nafkah, maskan and kiswah to his ex-wife during the iddah period. The obligation to give mut'ah aims to reduce the burden of the defendant's suffering as a wife due to the divorce based on $\mathrm{Al}$ Baqarah verse 241:

$$
\text { وَلِْلُْطَلَََّاتِ مَتَاعُ بِالْمَعْرُوفِ حَقَّا عَلَى الْمُتَّقِينَ }
$$

"And for divorced women is a provision according to what is acceptable - a duty upon the righteous" (QS. Al-Baqarah: 241).

Therefore, based on Article $160 \mathrm{KHI}$, the giving of mut'ah is made fit to suitability and ability of the husband. According to consideration of the panel of Judges on the plaintiff's occupation as ahead of the village while the defendant had accompanied him serving the role for 27 years and because the divorce granted is raj' $i$, the defendant has the right to obtain nafkah iddah from the plaintiff. 
Furthermore, the Assembly also considers it appropriate and reasonable if the plaintiff is sentenced to pay iddah cost to the defendant. In accordance with the facts at the hearing and occupation of the husband, the panel of judges determines the mut'ah and iddah cost with the following details: Rp. 4,500,000.00 (four million five hundred rupiah) for nafkah iddah; Rp. 1,500,000.00 (one million five hundred thousand rupiah) for $m u t^{\prime} a h$.

The panel of judges also stated that after the plaintiff's petition of divorce was granted and had permanent legal force, he will have the right to declare the divorce pledge on his wife without applying execution to the Court. The panel of judges also considered it fair if the wife automatically obtained her rights (nafkah mut'ah and iddah) at the time of the divorce pledge declaration without applying to execution to the Court. The legal argument is based on General Explanation number 7 of Law Number 7 of 1989 concerning Religious Courts which states "The Marriage Law aims to protect women in general and wives in particular" and the QS Al -Baqarah (2): 229 as follows:

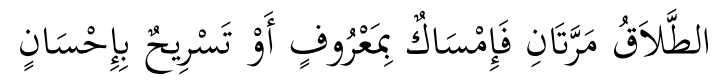

"Divorce is twice. Then, either keep [her] in an acceptable manner or release [her] with good treatment".28

The interpretation of (تَسْرِحْ :بإِحسَّانٍ) in the Al-Maraghi

commentaries book is:

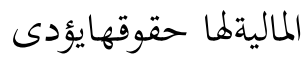

"Giving material rights to the wife". ${ }^{29}$

Based on those reasons, to enact justice and for the sake of ensuring the defendants' rights (mut'ah and nafkah iddah) get paid, the panel of judges seems it necessary to punish the plaintiff to pay

28 Departemen Agama RI, Alquran Dan Terjemahnya (Jakarta: Proyek Pengadaan Kitab Suci Al-Qur'an, 1985), 55.

29 Ahmad Mustofa Al-Maroghi, Tafsir Al-Maraghi (Beirut: Dar Al-Kutub Al-Alamiyah, 1971), 169. 
mut'ah and nafkah iddah according to legal considerations "shortly before declaring the divorce pledge".

The mention of the phrase "shortly before declaring the divorce pledge" is mandated by PERMA number 3 of 2017 concerning the certainty of payment method on the wife's rights after divorce. It is an effort of the panel of judges to empower women in the judiciary. Considering its ratification process, PERMA number 3 of 2017 is not a completely new regulation because in several MARI's National Work Meetings known as Rakernas, the partisanship commitment on women always becomes a discussion theme as well as decision.

For example, RAKERNAS of 2010 in Balikpapan ratified policies regarding legal reference in deciding marital disputes involving women and children in addition to the commonly used law in the Religious Courts (PA) consisting of Law number 1 of 1974 concerning marriage (UUP), Government Regulation Number 9 of 1975 (PP) concerning UUP Implementation, and Compilation of Islamic Law (KHI). It requires the judges of Religious Courts to seriously consider the provision in Act Number 23 of 2004 concerning the Elimination of Domestic Violence (PKDRT Law) and Law Number 23 of 2002 concerning Child Protection.

Furthermore, in the RAKERNAS of 2012 in Jakarta, a decision was made that in examining, adjudicating and deciding a case, the judges had to be responsive and progressive instead of positivistic. The existence of PERMA number 3 of 2017 can therefore be said as a policy that reinforces the previous policies and evidence that the Religious Court has tried various policies to strengthen women's empowerment.

Normatively, efforts on women's empowerment have been sought since the enforcement of divorce declaration rules before the Religious Court hearing. The formulators of the UUP and KHI had determined principles of the divorce through a judicial institution in Article 39 of the UUP paragraph (1) jo Article $115 \mathrm{KHI}$ jo Article 65 of Law Number 7 of 1989 concerning Religious Courts (UUPA) stating that "the divorce can only be conducted before a trial of the court after the court tried but failed to reconcile the two parties". 
Furthermore, the marriage dispute legal service mentioned that a divorce lawsuit filed by a wife must be filed at her residence (Article 73 paragraph 1 of the UUPA) while a husband who will file for divorce must submit his divorce petition to the court in his wife's residence (Article 66 paragraph 12 UUPA). More specifically, Article 41 (c) of the Indonesian Law in conjunction with Article 149 KHI also gives the ex officio authority to the court to be able to require the ex-husband to provide living expenses for his ex-wife through $m u t^{\prime} a h$, iddah, an owed dowry, and living cost for the child whom the mother takes care of.

Unfortunately, the regulation still copes with some constraints in its implementation due to the absence of rules regarding the mechanism or method and the deadline for payment. For this reason, PERMA number 3 of 2017 serves as a solutive regulation to overcome the problem of enforcing women's empowerment policies in the judiciary.

\section{Conclusion}

The study concludes that the implementation of PERMA number 3 of 2017 is an effort to empower women in Religious Court institutions. The implementation of the PERMA begins at the initial stage of the trial after mediation is declared unsuccessful. Judges actively explains the rights of wife and children to provide support to the wife and oblige the husband prepared for fulfilling his obligation. In certain circumstances, the judge uses his legal mandate to determine the rights of wives and children in ex officio or delaying the divorce pledge until it runs out of the time. Meanwhile, the constraints to implement the are the absence of the defendant in a trial which leads to the verstek verdict, husband's economic ability, wife's ignorance on the procedure for filing claims, judges' perspective problems and problems of derivative (technical) regulation of the PERMA which uses the diction "able". This tends to compromise instead of normative or imperative.

\section{Bibliography}

Ahmad Mustofa Al-Maroghi. Tafsir Al-Maraghi. Beirut: Dar AlKutub Al-Alamiyah, 1971. 
Aminah. "A Judge in Sampang Religious Court." n.d.

Anshori, D. S. (2016). Gender cognition in religious discourse: A study of framing in thematic holy koran interpretation. Indonesian Journal of Applied Linguistics, 6(1), 88-98. doi:10.17509/ijal.v6i1.2741

Amran Suadi. "Peranan Peradilan Agama Dalam Melindungi Hak Perempuan Dan Anak Melalui Putusan Yang Memihak Dan Dapat Dilaksanakan." Majalah Hukum Varia Peradilan Tahun XXXIII. No. 390 Mei 2018. Jakarta, 2018.

Acri, M., Zhang, S., Adler, J. G., \& Gopalan, G. (2017). Peerdelivered models for caregivers of children and adults with health conditions: A review. Journal of Child and Family Studies, 26(2), 337-344. doi:10.1007/s10826-016-0616-1

Affrunti, N. W., \& Woodruff-Borden, J. (2017). The roles of anxious rearing, negative affect, and effortful control in a model of risk for child perfectionism. Journal of Child and Family Studies, 26(9), 2547-2555. doi:10.1007/s10826-017-0767-8

Chinwuba, N. N. (2015). Ending inequality in nigeria: A refreshing approach from the nation's judiciary. International Journal of Law, Policy and the Family, 29(3), 341-350. doi:10.1093/lawfam/ebv010

Departemen Agama RI. Alquran Dan Terjemahnya. Jakarta: Proyek Pengadaan Kitab Suci Al-Qur'an, 1985.

Di Micaela, L. (2018). "Why can't they be like our grandparents?" and other racial fairy tales. Without justice for all: The new liberalism and our retreat from racial equality (pp. 29-64) doi:10.4324/9780429503047-3 Retrieved from www.scopus.com

Fadlilah. "A Judge in Bangkalan Religious Court." 2019.

Irianto, S. (2004). Competition and interaction between state law and customary law in the court room: A study of inheritance cases in indonesia. Journal of Legal Pluralism and Unofficial Law, 36(49), 91-112. doi:10.1080/07329113.2004.10756574

Johnny Ibrahim. Teori Dan Metodologi Penelitian Hukum Normatif. 6th ed. Malang: Bayumedia Publishing, 2012.

Kharlie, Ahmad Tholabi. "Modernisasi, Tradisi, Dan Identitas: Praktik Hukum Keluarga Islam Indonesia." Studia Islamika 18, 
no. 1 (2011): 167-99. https://doi.org/10.15408/sdi.v18i1.444.

Kompilasi Hukum Islam (1991).

Lawrence M. Friedman. Sistem Hukum Perspektif Ilmu Sosial. Edited by M. Khozin. Bandung: Nusamedia, 2013.

Lexy J Moleong. Metodologi Penelitian Kualitatif. Bandung: Remaja Rosdakarya, 1990.

Nasution, Khoiruddin. "Peran Kursus Nikah Membangun Keluarga Sejahtera." AHKAM:Jurnal Ilmu Syariah 15, no. 2 (March 2016). https:// doi.org/10.15408/ajis.v15i2.2862.

Nauval Rikza. "Pengaruh PERMA No. 3 Tahun 2017 Terhadap Perkara Perceraian Di Pengadilan Kabupaten Kediri." Universitas Muhammadiyah Surakarta, n.d.

Nurul Hakimah. "A Judge in Sampang Religious Court." n.d.

"PERMA Nomor 3 Tahun 2017 Tentang Pedoman Mengadili Perkara Perempuan Berhadapan Dengan Hukum," 2018.

Silmi Mursidah. "Analisis Maslahah Terhadap PERMA No. 3 Tahun 2017 Tentang Pedoman Mengadili Perkara Perempuan Berhadapan Dengan Hukum." UIN Sunan Ampel Surabaya, 2017.

Siti Musawwamah. "Perlindungan Hak-Hak Perempuan Dan Anak Pada Putusan Perceraian Di Pengadilan Agama Pamekasan Tahun 2012-2014." UIN Sunan Kalijaga Yogyakarta, 2019.

Siti Musawwamah et al. "Penelitian Sosio-Legal Penyelesaian Kasus KDRT Di Pengadilan Agama Wilayah Madura," 2015.

Sumargi, A., Filus, A., Morawska, A., \& Sofronoff, K. (2018). The parenting and family adjustment scales (PAFAS): An indonesian validation study. Journal of Child and Family Studies, 27(3), 756-770. doi:10.1007/s10826-017-0926-y

Soemadiningrat, R Otje Salman. Rekonseptualisasi Hukum Adat Kontemporer: Telaah Kritis Terhadap Hukum Adat Sebagai Hukum Yang Hidup Dalam Masyarakat. Bandung: PT Alumni, 2002.

Syahrul, Ninawati. "Peran dan Tanggung Jawab Mamak dalam Keluarga: Tinjauan Terhadap Novel Salah Asuhan Karya Abdoel Moeis". Metasastra, Vol. 10, No. 1, (Juni, 2017).

Subramanian, Narendra. "Islamic Norms, Common Law, and Legal Reasoning: Muslim Personal Law and the Economic 
Consequences of Divorce in India." Islamic Law and Society 24, no. 3 (2017): 254-86. https://doi.org/10.1163/15685195$00243 p 03$.

Sulhan Fadlil. "The Chief of Sumenep Religious Court." n.d.

Syaiful Annas. "Masa Pembayaran Beban Nafkah Iddah Dan Mut'ah Dalam Perkara Cerai Talak (Sebuah Implementasi Hukum Acara Di Pengadilan Agama)." Al-Ahwal 10, no. 1 Juni (2017).

Umniyah. "A Judge in Pamekasan Religious Court." n.d.

Zainuddin Ali. Metode Penelitian Hukum. 4th ed. Jakarta: Sinar Grafika, 2013. 